\title{
Increased iron content in the heart of the Fmrl knockout mouse
}

\author{
Karo Talvio • Katja M. Kanninen • Anthony R. White • Jari Koistinaho • \\ Maija L. Castrén
}

Received: 28 November 2020/ Accepted: 24 May 2021/Published online: 5 June 2021

(C) The Author(s) 2021

\begin{abstract}
Trace elements have important functions in several processes involved in cellular homeostasis and survival. Dysfunctional metal ion homeostasis can make an important impact on cellular defence mechanisms. We assessed the concentrations of 23 trace minerals in different tissues (brain, spleen, heart and liver) of Fmrl knockout (KO) mice that display the main phenotype of Fragile X syndrome (FXS), an intellectual disability syndrome and the best-known monogenic model of autism spectrum disorder (ASD).
\end{abstract}

Supplementary Information The online version contains supplementary material available at https://doi.org/10.1007/ s10534-021-00320-1.

K. Talvio - M. L. Castrén $(\bowtie)$

Faculty of Medicine, Physiology, University of Helsinki, P.O. Box 63, 00290 Helsinki, Finland

e-mail: maija.castren@helsinki.fi

K. M. Kanninen · J. Koistinaho

A.I. Virtanen Institute for Molecular Sciences, University of Eastern Finland, Kuopio, Finland

\section{A. R. White}

Department of Pathology, University of Melbourne, Melbourne, VIC, Australia

\section{A. R. White}

Cell and Molecular Biology, QIMR Berghofer Medical

Research Institute, Brisbane, QLD, Australia

J. Koistinaho

Neuroscience Center, HiLIFE, University of Helsinki,

Helsinki, Finland
Altogether, seven minerals- $\mathrm{Cu}, \mathrm{Fe}, \mathrm{K}, \mathrm{Mg}, \mathrm{Mn}, \mathrm{Na}$, and $\mathrm{P}$-were above the detection limit with the analysis revealing increased iron content in the heart of Fmrl KO mice. In addition, levels of iron were higher in the cerebellum of the transgenic mouse when compared to wild type controls. These results implicate a role for dysregulated iron homeostasis in FXS tissues and suggest that defective iron-related mechanisms contribute to increased tissue vulnerability in FXS.

Keywords Trace elements $\cdot$ Metals $\cdot$ Autism · Fragile X syndrome

\section{Introduction}

Fragile X syndrome (FXS) is an intellectual disability syndrome with a prevalence of around 1/4000 in males and 1/6000-8000 in females (Crawford et al. 1999). The FXS neurobehavioral phenotype includes abnormalities in speech development and communication, social behaviour, sensory reactivity, attention, arousal, and activity levels (Hagerman et al. 2010). The vast majority of FXS males display some behaviours characteristic of individuals with autism spectrum disorder (ASD) with some $(\sim 10-30 \%)$ fulfilling the standardised criteria for ASD (Brown et al. 1986). FXS is a monogenic disorder caused by the absence of FMR1 protein (FMRP) and the Fmrl knockout (KO) 
mouse recapitulates the human FXS phenotype. In most FXS patients, a CGG triple repeat expansion comprising $>200$ repeats leads to transcriptional silencing of the FMRI gene (O'Donnell and Warren 2002). The length of the repeated CGG sequence of the FMR 1 gene in the range of 6-44 repeats is normal, whereas 45-54 repeats is intermediate or grey area, and 55-200 repeats is considered as premutation (Verkerk et al. 1991; Penagarikano et al. 2007). The premutation causes increased FMRI mRNA levels that associates with slightly reduced FMRP expression and does not result in any neurodevelopmental syndrome, but can lead to the onset of Fragile X-associated Tremor/Ataxia Syndrome (FXTAS) after the age of 50 years (Loesch and Hagerman 2012).

An inappropriate intake or absorption of trace elements is associated with a variety of health problems. Altered metal homeostasis is linked to a number of disorders and heavy metal exposure is presented as a potential risk factor for neurodevelopmental disorders (Froehlich et al. 2011; Scassellati et al. 2012; Kanninen et al. 2013). It has been suggested that metal deficiency and/or toxic metal burdens may epigenetically contribute to the manifestation of ASD (Yasuda et al. 2013). However, several studies searching changes of trace elements/metals in ASD have generated inconsistent results with high individual variation in levels of minerals (Saghazadeh et al. 2017; Tseng et al. 2018; Curtin et al. 2018; Austin et al. 2019; Hassan et al. 2019). Studies of genetic mouse models of neurodevelopmental diseases could provide important additional information about the relationship of trace metal balance and ASD.

Metal ions are tightly linked to the redox state of a cell. Oxidative stress is elevated in the brain of Fmrl KO mice (El Bekay et al. 2007), but tissue trace element homeostasis has not been previously examined in FXS. We investigated biometal concentrations in different tissues of the Fmrl KO mice. Using sensitive inductively coupled plasma mass spectrometry (ICP-MS) to analyse trace elements, seven minerals were reliably detected in mouse tissues and iron content proved to be increased in the heart of the Fmrl KO mouse.

\section{Methods}

Mice

Fmrl KO mice (B6.129P2-Fmr1tm1/Cgr/J, Jackson Laboratory, Bar Harbor, ME) and their wild type (WT) littermates were used at the age of 4-5 months. Genotyping by tail-PCR was performed as previously described (Bakker et al. 1994). Mice were housed in groups and subjected to a 12-h light-dark cycle with access to food and water ad libitum. All animal experiments were done in accordance with the guidelines of the National Institute of Health Guide for the Care and Use of Laboratory Animals and carried out using protocols approved by the Experimental Animal Ethical Committee of Southern Finland.

\section{Mouse tissues}

For tissue collection, mice were anaesthetised with carbon dioxide and sacrificed by cervical dislocation. Brains, spleens, hearts, and livers were collected. Cerebellums and the ventral regions of the cerebral cortex were further dissected. The tissue pieces were weighed. There were no differences of average wet weights $(p<0.05)$ between control and FXS tissue samples (Table 1). All tissues were snap frozen and stored at $-80{ }^{\circ} \mathrm{C}$ until use.

\section{Mass-spectrometry analysis}

The tissue concentrations of trace elements were measured by an established and fully validated method using ICP-MS as described previously (Maynard et al. 2002; Kanninen et al. 2013). Due to technical problems, four samples were not processed (Fmrl KO cortex, WT liver and both Fmrl KO and WT cerebellum). Briefly, weighed tissue samples were lyophilised, digested in 100-300 $\mu \mathrm{l}$ of $65 \%$ nitric acid (Merck, Kilsyth, Victoria, Australia) overnight at room temperature (RT), and heated for $20 \mathrm{~min}$ at $90{ }^{\circ} \mathrm{C}$. Then an equivalent volume of $30 \%$ hydrogen peroxide (30\% Aristar, BDH) was added and samples were incubated for $30 \mathrm{~min}$ at RT, followed by $15 \mathrm{~min}$ at $70{ }^{\circ} \mathrm{C}$. The average reduced volume was determined, and the samples were diluted with $1 \%$ nitric 
Table 1 Sample preparation

\begin{tabular}{llllllll}
\hline Tissue & $\mathrm{N}$ & $\begin{array}{l}\text { Average weight }(\mathrm{mg}) \\
\text { WT }\end{array}$ & $\begin{array}{l}\text { Average weight }(\mathrm{mg}) \\
\text { Fmrl KO }\end{array}$ & $\begin{array}{l}\mathrm{HNO}_{3} \\
\text { volume }(\mu \mathrm{l})\end{array}$ & $\begin{array}{l}\text { Reduced } \\
\text { volume }(\mu \mathrm{l})\end{array}$ & $\begin{array}{l}\text { Dilution } \\
\text { factor }\end{array}$ & $\begin{array}{l}\text { Vol of } \\
\text { digest }(\mu \mathrm{l})\end{array}$ \\
\hline Cerebellum & 12 & $63 \pm 5.9$ & $52 \pm 8$ & 100 & 150 & 21 & 50 \\
Cortex & 12 & $140 \pm 5.2$ & $140 \pm 11$ & 100 & 135 & 21 & 50 \\
Heart & 14 & $82 \pm 8$ & $59 \pm 7$ & 150 & 210 & 21 & 50 \\
Liver & 12 & $170 \pm 20$ & $160 \pm 17$ & 300 & 470 & 51 & 30 \\
Spleen & 13 & $56 \pm 6.9$ & $70 \pm 4.4$ & 150 & 210 & 21 & 50 \\
\hline
\end{tabular}

Sample weights are mean \pm SEM

acid diluent using dilution factors as shown in Table 1. Volume of digest was the amount of the digested sample that was used to make the dilution.

Measurements were made with an Agilent 7700 series ICP-MS instrument (Agilent Technologies, Santa Clara, CA, USA) under routine multi-element operating conditions using helium as cell gas. The instrument was calibrated using $0,5,10,50$, and $100 \mathrm{ppb}$ of certified multi-element standard calibration solutions (ICP-MS-CAL2-1, ICP-MS-CAL-3, and ICP-MS-CAL-4; Accustandard, New Haven, CT, USA) for the range of the elements and $200 \mathrm{ppb}$ of Yttrium (Y89) was used as internal control (ICPMS-IS-MIX1-1, Accustandard). Three media blanks were used to determine detection limits. Conversion of readings in $\mathrm{ppb}$ was performed as follows: $(\mu \mathrm{g} /$ $\mathrm{g})=($ raw ppb value $\times$ dilution factor $\times$ reduced digest volume)/(tissue wet weight $g$ ). Samples were analysed in triplicate and median values were used for analyses. Results are expressed in micrograms of metal per gram of wet $(\mu \mathrm{g} / \mathrm{g}$ wet wt). The concentration of 23 minerals and trace elements were assessed in mouse heart, liver, spleen, and brain tissues.
Altogether, 7 trace elements $(\mathrm{Cu}, \mathrm{Fe}, \mathrm{K}, \mathrm{Mg}, \mathrm{Mn}$, $\mathrm{Na}$, and $\mathrm{P}$ ) were above detection limits in our set of samples (Table 2), whereas 16 trace elements (Al, B, $\mathrm{Ba}, \mathrm{Ca}, \mathrm{Cd}, \mathrm{Co}, \mathrm{Cr}, \mathrm{Li}, \mathrm{Mo}, \mathrm{Ni}, \mathrm{Rb}, \mathrm{Ru}, \mathrm{Se}, \mathrm{Sr}, \mathrm{Ti}$, and $\mathrm{Zn}$ ) could not be reliably detected.

Statistical analysis

Statistical significance between KO and WT mouse tissues with each variable was determined with the Student's $t$-test. The principal component analysis (PCA) was performed with all 35 metal variables (7 elements in 5 tissues). In the analysis, two WT mice were excluded due to several missing values and the missing values were replaced with the means when maximum of two tissues were missing. All statistical analyses, including linear correlations across all variables, were carried out using IBM SSPS Statistics. Data are shown as mean \pm standard deviation. The criterion for significance was set to $\mathrm{p}<0.05$.
Table 2 The absolute metal content in the set of WT tissue samples of average size and concentrations of the medium and acid blanks

\begin{tabular}{llllllll}
\hline Metal & Cortex & Cerebellum & Liver & Spleen & Heart & $\begin{array}{l}\text { Media blank } \\
(\mu \mathrm{g} / \mathrm{g})\end{array}$ & $\begin{array}{l}\text { Acid } \\
\text { blank } \\
(\mu \mathrm{g} / \mathrm{g})\end{array}$ \\
\hline $\mathrm{Na}(\mu \mathrm{g})$ & 210 & 96 & 130 & 38 & 98 & 25 & 32 \\
$\mathrm{Mg}(\mu \mathrm{g})$ & 14 & 7.5 & 36 & 9.2 & 14 & 0.69 & 0.31 \\
$\mathrm{P}(\mu \mathrm{g})$ & 330 & 190 & 530 & 180 & 170 & 4.2 & 2.5 \\
$\mathrm{~K}(\mu \mathrm{g})$ & 330 & 160 & 500 & 180 & 160 & 4.1 & 5.4 \\
$\mathrm{Mn}(\mathrm{ng})$ & 29 & 21 & 120 & 8.2 & 31 & 0.013 & 0 \\
$\mathrm{Fe}(\mathrm{ng})$ & 910 & 540 & 12,000 & 26,000 & 3500 & 0.29 & 0 \\
$\mathrm{Cu}(\mathrm{ng})$ & 300 & 200 & 720 & 36 & 360 & 0.076 & 0.0016 \\
\hline
\end{tabular}




\section{Results}

Mean metal concentrations of WT and KO mouse tissues are presented in Table 3. Most significantly, iron was increased in the hearts $(\mathrm{p}=0.033)$ of the KO mice (Fig. 1). The highest iron content was seen in spleen and the levels were relatively low in the brain tissues. An increase in iron content in the cerebellum of the Fmrl KO was found at the marginal level of significance $(p=0.052)$. The methodology suffered from low power and these statistical significances should be considered in the context of 35 individual comparisons ( 7 metals in 5 tissues) between $\mathrm{KO}$ and WT mice (Bonferroni correction for a typical $\alpha=0.05$ with 35 comparisons $\mathrm{p}<0.0014$, and the family-wise error rate for 35 comparisons at $\alpha=0.05$ was 0.83 ).

To evaluate the complete dataset for pattern of variations, we used the PCA. Three components were extracted, explaining a total of $73 \%$ of the total

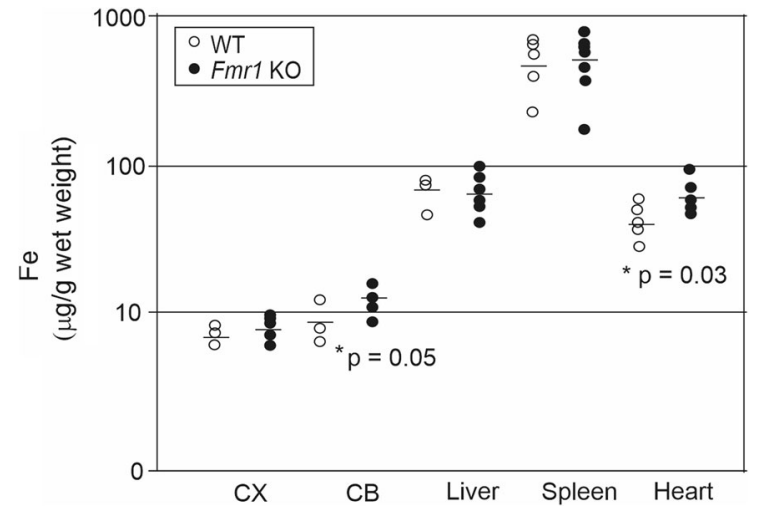

Fig. 1 Concentration of iron across tissues. Values for individual Fmrl KO and WT mice are plotted. *p $\leq 0.05$

variance; PC1 explained 35\%, PC2 23\%, and PC3 $15 \%$. PC1 correlated closely with brain and spleen variables. PC2 correlated with heart variables and PC3 was influenced mostly by liver variables. T-tests with

Table 3 Concentrations of different metals in heart, spleen, liver, cerebellum, and cortex of Fmrl KO mice compared to WT controls

\begin{tabular}{|c|c|c|c|c|c|c|}
\hline Metal & & Cortex & Cerebellum & Liver & Spleen & Heart \\
\hline \multirow[t]{3}{*}{$\mathrm{Na}(\mu \mathrm{g} / \mathrm{g})$} & WT & $1500 \pm 97$ & $1500 \pm 360$ & $790 \pm 110$ & $680 \pm 220$ & $1200 \pm 230$ \\
\hline & Fmrl KO & $1500 \pm 230$ & $1900 \pm 330$ & $730 \pm 73$ & $590 \pm 160$ & $1400 \pm 380$ \\
\hline & $\mathrm{p}$ & 0.83 & 0.21 & 0.39 & 0.41 & 0.19 \\
\hline \multirow[t]{3}{*}{$\mathrm{Mg}(\mu \mathrm{g} / \mathrm{g})$} & WT & $100 \pm 13$ & $120 \pm 36$ & $210 \pm 19$ & $160 \pm 51$ & $170 \pm 48$ \\
\hline & Fmrl KO & $95 \pm 18$ & $140 \pm 38$ & $210 \pm 31$ & $150 \pm 34$ & $210 \pm 48$ \\
\hline & $\mathrm{p}$ & 0.61 & 0.4 & 0.8 & 0.51 & 0.16 \\
\hline \multirow[t]{3}{*}{$P(\mu \mathrm{g} / \mathrm{g})$} & WT & $2300 \pm 280$ & $3100 \pm 980$ & $3100 \pm 240$ & $3200 \pm 1000$ & $2100 \pm 630$ \\
\hline & Fmrl KO & $2300 \pm 420$ & $3600 \pm 1000$ & $3000 \pm 430$ & $2900 \pm 720$ & $2500 \pm 550$ \\
\hline & $\mathrm{p}$ & 0.82 & 0.41 & 0.5 & 0.55 & 0.23 \\
\hline \multirow[t]{3}{*}{$\mathrm{K}(\mu \mathrm{g} / \mathrm{g})$} & WT & $2400 \pm 300$ & $2500 \pm 810$ & $2900 \pm 190$ & $3200 \pm 1000$ & $2000 \pm 640$ \\
\hline & Fmrl KO & $2300 \pm 420$ & $3100 \pm 800$ & $3100 \pm 420$ & $2900 \pm 670$ & $2700 \pm 600$ \\
\hline & $\mathrm{p}$ & 0.67 & 0.35 & 0.53 & 0.49 & 0.069 \\
\hline \multirow[t]{3}{*}{$\operatorname{Mn}(\mu \mathrm{g} / \mathrm{g})$} & WT & $0.21 \pm 0.014$ & $0.33 \pm 0.093$ & $0.71 \pm 0.05$ & $0.15 \pm 0.064$ & $0.38 \pm 0.083$ \\
\hline & $F m r l \mathrm{KO}$ & $0.19 \pm 0.039$ & $0.36 \pm 0.097$ & $0.79 \pm 0.13$ & $0.16 \pm 0.05$ & $0.49 \pm 0.15$ \\
\hline & $\mathrm{p}$ & 0.39 & 0.69 & 0.14 & 0.69 & 0.11 \\
\hline \multirow[t]{3}{*}{$\mathrm{Fe}(\mu \mathrm{g} / \mathrm{g})$} & WT & $6.6 \pm 0.91$ & $8.6 \pm 2.6$ & $70 \pm 15$ & $460 \pm 200$ & $43 \pm 11$ \\
\hline & Fmrl KO & $7.6 \pm 1.5$ & $13 \pm 2.8$ & $66 \pm 19$ & $510 \pm 190$ & $62 \pm 17$ \\
\hline & $\mathrm{p}$ & 0.18 & 0.052 & 0.74 & 0.7 & $0.033 *$ \\
\hline \multirow[t]{3}{*}{$\mathrm{Cu}(\mu \mathrm{g} / \mathrm{g})$} & WT & $2.2 \pm 0.27$ & $3.2 \pm 1.7$ & $4.2 \pm 0.93$ & $0.64 \pm 0.21$ & $4.4 \pm 1.2$ \\
\hline & Fmrl KO & $2 \pm 0.44$ & $4.4 \pm 1.1$ & $4.2 \pm 1.2$ & $0.55 \pm 0.13$ & $5.5 \pm 1.4$ \\
\hline & $\mathrm{p}$ & 0.39 & 0.31 & 0.96 & 0.44 & 0.16 \\
\hline
\end{tabular}

$* \mathrm{p}<0.05$ 
respect to the genotype on each extracted principal component showed that $\mathrm{KO}$ and WT mice segregated across PC2 ( $p=0.031)$, but not across PC1 $(p=0.9)$ or PC3 $(p=0.99)$, implicating altered biometal homeostasis in the heart of the Fmrl KO mouse. Subject mice by genotype and variables by the tissue of the variable are shown in Fig. 2.

Brain and liver metal levels measured in the present study were comparable to previously reported measurements in mouse and rat tissues (SATO et al. 1996; Schneider et al. 2014; Garza-Lombó et al. 2018). In our analysis, within a tissue, metal concentrations generally correlated positively, but negatively with the mass of the tissue sample. Furthermore, we observed that $\mathrm{Mg}$ correlated strongly $(\mathrm{r}>0.95)$ with $\mathrm{P}$ and $\mathrm{K}$ in most tissues, whereas $\mathrm{Cu}$ correlated strongly with $\mathrm{P}$, $\mathrm{Mg}$ and $\mathrm{K}$ in spleens and hearts. A correlation matrix is provided in Online Resource 1.

\section{Discussion}

The present study demonstrated elevations of iron levels in heart and cerebellum of the Fmrl KO mouse.
Iron is a redox-active metal and an essential component of many proteins involved in biological defence mechanisms against oxidative stress (Crichton and Pierre 2001). A moderate increase in stress status has been previously reported in the adult Fmrl KO mouse brain, reflecting a deficient antioxidant system together with higher levels of reactive oxygen species, nicotinamide adenine dinucleotide phosphate (NADPH) -oxidase activation, lipid peroxidation and protein oxidation (El Bekay et al. 2007). Furthermore, studies of human FMRl premutation fibroblasts have revealed mitochondrial chain dysfunction and abnormally increased reactive oxygen species (ROS) production, which responded to chelation of iron with desferrioxamine mesylate (DFO) (Napoli et al. 2011). Since the FMRI premutation alters FMRI transcript expression and slightly reduces FMRP levels, the findings are consistent with involvement of FMRP in the regulation of iron balance.

FMRP has previously been implicated in protective mechanisms against injury in heart (Bao et al. 2018). Overexpression of FMRP was found to alleviate oxidative stress and apoptosis in damaged cardiomyocytes. Many FXS patients suffer from dilatation of

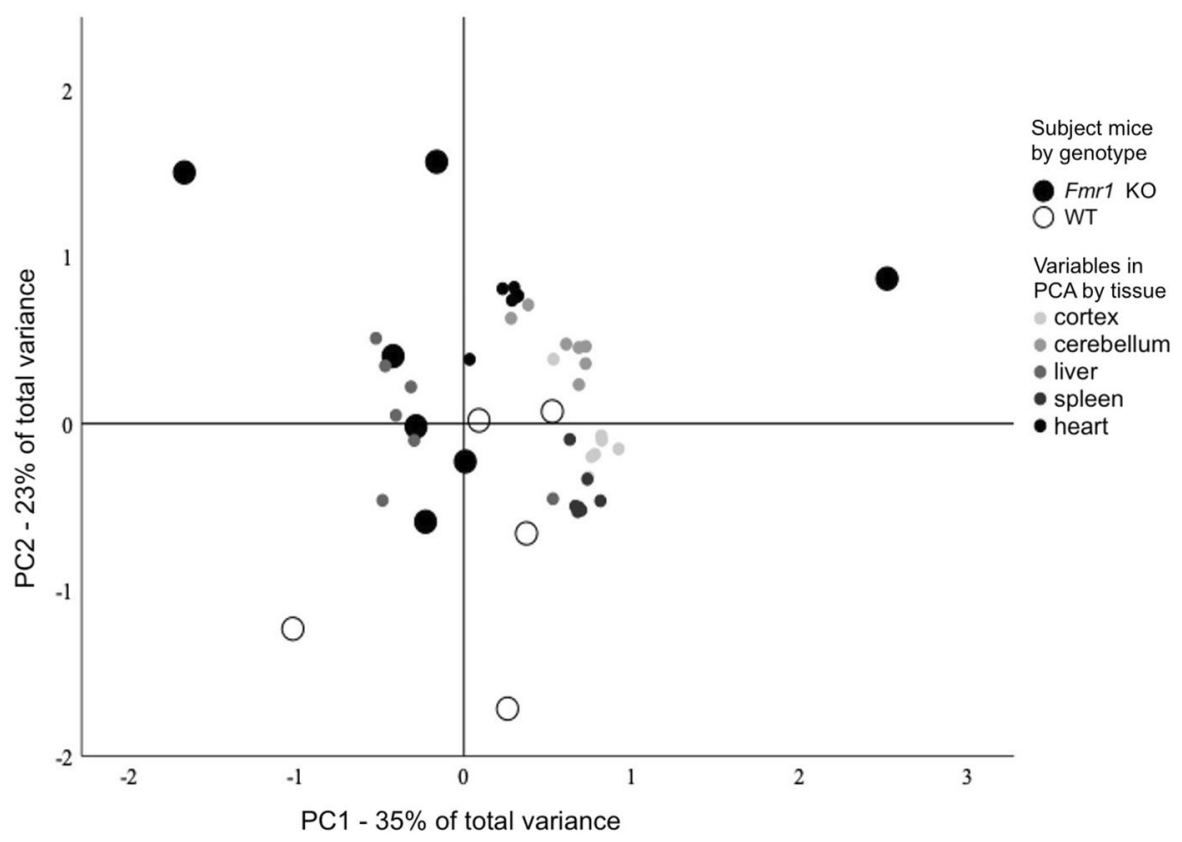

Fig. 2 Principal component analysis (PCA) that was used to classify Fmrl KO and WT mice based on metal content of seven different metals in five tissues is shown with respect to PC1 and PC2. KO and WT mice segregated across PC2 $(p=0.031)$ that explained $35 \%$ of the total variance and correlated with heart variables. Variables are coded by colour with respect to tissue studied 
aortic root and mitral valve prolapse that have been linked to connective tissue dysplasia. There is also evidence that sympathetic activity augments cardiac activity and output in FXS more than in healthy controls (Sreeram et al. 1989). A 1.4-fold increase in iron content in the heart tissue of Fmrl KO mouse provides evidence of pathological cellular processes, but its impact on heart function remains to be investigated. The extent of iron toxicity depends on localisation of the iron complex within the cell e.g. cytosolic vs. lysosomal, its biochemical form, and the cellular content of a wide range of antioxidants and cytoprotective enzymes that can prevent the generation and propagation of free radical species. Mitochondrial iron accumulation in cardiac tissue and brain is associated with Friedrich ataxia (FRDA). The excess iron exists as highly localized multifocal aggregates rather than a diffuse pattern in the tissue of FRDA patients and iron-mediated toxicity is not well understood (Llorens et al. 2019).

Region-specific accumulation of iron can particularly contribute to the pathophysiology of brain diseases due to the decreased ability of neuronal cells to respond to oxidative stress. Increased iron levels have been linked to abnormalities of cerebellar myelination (Beltrán-Navarro et al. 2012; Klocke et al. 2018; Fernández et al. 2019). Accumulation of iron in the cerebellum of the Fmrl $\mathrm{KO}$ mice is especially interesting considering the cerebellar changes and altered firing rate of neurons in cerebellar circuitry of Fmrl KO mice (Koekkoek et al. 2005). Cerebellar vermis is essential in gating of sensorimotor reactions (Leaton and Supple 1986), and impaired acoustic startle reflex in human and mouse models of FXS also supports involvement of cerebellar defects in FXS. Cerebellum was not studied as a separate brain region in the oxidative stress study of Fmrl KO mice by el Bekay et al. (2007). Mild cerebellar accumulation of iron was previously shown in a subset of FMRI premutation carriers with FXTAS (Rogers et al. 2016), who display defective iron and zinc metabolism (Napoli et al. 2011).

Biometal supplements are used without medical prescription and are often tested as treatment of neurodevelopmental disorders when no other treatment is available. Current research data do not provide sufficient information to formulate recommendations for use of trace elements/metals (Lyall et al. 2014; Devilbiss et al. 2017). Iron is important for normal behavioural development and its deficiency is often seen in ASD patients (Latif et al. 2002). However, altered iron levels in ASD may be primarily of environmental origin and not directly linked to ASD (Reynolds et al. 2012). Mouse models offer possibilities to investigate disease-related biometal homeostasis and to evaluate the effectiveness of treatments. It is important to note that accumulation of trace elements may increase the risk of tissue damage. Our observation that heart iron content was increased in the FXS mouse may have clinical impact, because increased cardiac iron levels can lead to iron overload cardiomyopathy, a potentially lethal condition. Furthermore, our study suggests that brain region-specific alterations of iron exist in FXS. Altogether, the present findings showing accumulation of iron in distinct Fmrl KO mouse tissues are fundamental and promote further research to evaluate role of biometals in FXS and other neurodevelopmental disorders.

Acknowledgements The authors thank Venkat Swaroop Aschuta for help in collecting the mouse tissue samples, Alexandra Grubman for assistance with sample analysis, and Erin Alderson for critical comments on the manuscript. This work was supported by grants from the Arvo and Lea Ylppö Foundation and the Academy of Finland.

Author contributions KT: Data curation, Visualisation, Original draft preparation; KK: Methodology, Data collection; AW: Supervision, Methodology; MC: Conceptualisation, Writing the manuscript, and together with JK Project administration.

Funding Open access funding provided by University of Helsinki including Helsinki University Central Hospital.

\section{Declarations}

Conflict of interest The authors declare that they have no competing interests.

Open Access This article is licensed under a Creative Commons Attribution 4.0 International License, which permits use, sharing, adaptation, distribution and reproduction in any medium or format, as long as you give appropriate credit to the original author(s) and the source, provide a link to the Creative Commons licence, and indicate if changes were made. The images or other third party material in this article are included in the article's Creative Commons licence, unless indicated otherwise in a credit line to the material. If material is not included in the article's Creative Commons licence and your intended use is not permitted by statutory regulation or exceeds the permitted use, you will need to obtain permission directly from the copyright holder. To view a copy of this licence, visit http://creativecommons.org/licenses/by/4.0/. 


\section{References}

Austin C, Curtin P, Curtin A et al (2019) Dynamical properties of elemental metabolism distinguish attention deficit hyperactivity disorder from autism spectrum disorder. Transl Psychiatry 9(1):238. https://doi.org/10.1038/ s41398-019-0567-6

Bakker CE, Verheij C, Willemsen R et al (1994) Fmr1 knockout mice: a model to study fragile $\mathrm{X}$ mental retardation. Cell 78(1):23-33. 8674(94)90569-X https://doi.org/10.1016/0092-

Bao J, Ye C, Zheng Z et al (2018) Fmr1 protects cardiomyocytes against lipopolysaccharide-induced myocardial injury. Exp Ther Med 16(3):1825-1833. https://doi.org/10.3892/ etm.2018.6386

Beltrán-Navarro B, Matute E, Vásquez-Garibay E et al (2012) Effect of chronic iron deficiency on neuropsychological domains in infants. J Child Neurol 27(3):297-303. https:// doi.org/10.1177/0883073811416867

Brown WT, Jenkins EC, Cohen IL et al (1986) Fragile X and autism: a multicenter survey. Am J Med Genet 23(1-2):341-352. https://doi.org/10.1002/ajmg. 1320230126

Crawford DC, Meadows KL, Newman JL et al (1999) Prevalence and phenotype consequence of FRAXA and FRAXE alleles in a large, ethnically diverse, special educationneeds population. Am J Hum Genet 64(2):495-507. https://doi.org/10.1086/302260

Crichton RR, Pierre JL (2001) Old iron, young copper: from Mars to Venus. Biometals 14(2):99-112. https://doi.org/ 10.1023/a:1016710810701

Curtin P, Austin C, Curtin A et al (2018) Dynamical features in fetal and postnatal zinc-copper metabolic cycles predict the emergence of autism spectrum disorder. Sci Adv 4(5): eaat1293. https://doi.org/10.1126/sciadv.aat1293

DeVilbiss EA, Magnusson C, Gardner RM et al (2017) Antenatal nutritional supplementation and autism spectrum disorders in the Stockholm youth cohort: population based cohort study. BMJ 359:j4273. https://doi.org/10.1136/bmj. j4273

El Bekay R, Romero-Zerbo Y, Decara J et al (2007) Enhanced markers of oxidative stress, altered antioxidants and NADPH-oxidase activation in brains from Fragile $\mathrm{X}$ mental retardation 1-deficient mice, a pathological model for Fragile $X$ syndrome. Eur $J$ Neurosci 26(11):3169-3180. https://doi.org/10.1111/j.1460-9568. 2007.05939.x

Fernández M, Sierra-Arregui T, Peñagarikano O (2019) The Cerebellum and Autism: More than Motor Control. In: Palermo S (ed) Behavioral Neuroscience. IntechOpen, London. https://doi.org/10.5772/intechopen.85897

Froehlich TE, Anixt JS, Loe IM et al (2011) Update on environmental risk factors for attention-deficit/hyperactivity disorder. Curr Psychiatry Rep 13(5):333-344. https://doi. org/10.1007/s11920-011-0221-3

Garza-Lombó C, Posadas Y, Quintanar L et al (2018) Neurotoxicity linked to dysfunctional metal ion homeostasis and xenobiotic metal exposure: redox signaling and oxidative stress. Antioxid Redox Signal 28(18):1669-1703. https:// doi.org/10.1089/ars.2017.7272
Hagerman R, Hoem G, Hagerman P (2010) Fragile X and autism: intertwined at the molecular level leading to targeted treatments. Mol Autism 1(1):12. https://doi.org/10.1186/ 2040-2392-1-12

Hassan MH, Desoky T, Sakhr HM et al (2019) Possible metabolic alterations among autistic male children: clinical and biochemical approaches. J Mol Neurosci 67(2):204-216. https://doi.org/10.1007/s12031-018-1225-9

Kanninen KM, Grubman A, Meyerowitz J et al (2013) Increased zinc and manganese in parallel with neurodegeneration, synaptic protein changes and activation of Akt/GSK3 signaling in ovine CLN6 neuronal ceroid lipofuscinosis. PLoS ONE 8(3):e58644. https://doi.org/10.1371/journal.pone. 0058644

Klocke C, Sherina V, Graham UM et al (2018) Enhanced cerebellar myelination with concomitant iron elevation and ultrastructural irregularities following prenatal exposure to ambient particulate matter in the mouse. Inhal Toxicol 30(9-10):381-396. https://doi.org/10.1080/08958378. 2018.1533053

Koekkoek SKE, Yamaguchi K, Milojkovic BA et al (2005) Deletion of FMR1 in Purkinje cells enhances parallel fiber LTD, enlarges spines, and attenuates cerebellar eyelid conditioning in fragile $\mathrm{X}$ syndrome. Neuron 47(3):339-352. https://doi.org/10.1016/j.neuron.2005.07. 005

Latif A, Heinz P, Cook R (2002) Iron deficiency in autism and Asperger syndrome. Autism 6(1):103-114. https://doi.org/ $10.1177 / 1362361302006001008$

Leaton R, Supple W (1986) Cerebellar vermis: essential for long-term habituation of the acoustic startle response. Science 232(4749):513-515. https://doi.org/10.1126/ science. 3961494

Llorens JV, Soriano S, Calap-Quintana P et al (2019) The role of iron in Friedreich's Ataxia: insights from studies in human tissues and cellular and animal models. Front Neurosci 13:75. https://doi.org/10.3389/fnins.2019.00075

Loesch D, Hagerman R (2012) Unstable mutations in the FMR1 gene and the phenotypes. Adv Exp Med Biol 769:78-114. https://doi.org/10.1007/978-1-4614-5434-2_6

Lyall K, Schmidt RJ, Hertz-Picciotto I (2014) Maternal lifestyle and environmental risk factors for autism spectrum disorders. Int J Epidemiol 43(2):443-464. https://doi.org/10. 1093/ije/dyt282

Maynard CJ, Cappai R, Volitakis I et al (2002) Overexpression of Alzheimer's disease amyloid- $\beta$ opposes the age-dependent elevations of brain copper and iron. J Biol Chem 277(47):44670-44676. https://doi.org/10.1074/jbc. M204379200

Napoli E, Ross-Inta C, Wong S et al (2011) Altered zinc transport disrupts mitochondrial protein processing/import in fragile $\mathrm{X}$-associated tremor/ataxia syndrome. Hum Mol Genet 20(15):3079-3092. https://doi.org/10.1093/hmg/ ddr211

O'Donnell WT, Warren ST (2002) A decade of molecular studies of fragile $\mathrm{X}$ syndrome. Annu Rev Neurosci 25:315-338. https://doi.org/10.1146/annurev.neuro.25. 112701.142909

Penagarikano O, Mulle JG, Warren ST (2007) The pathophysiology of fragile x syndrome. Annu Rev Genomics Hum 
Genet 8:109-129. https://doi.org/10.1146/annurev.genom. 8.080706.092249

Reynolds A, Krebs NF, Stewart PA et al (2012) Iron status in children with autism spectrum disorder. Pediatrics 130(Supplement 2):S154-S159. https://doi.org/10.1542/ peds.2012-0900M

Rogers H, Ariza J, Monterrubio A et al (2016) Cerebellar mild iron accumulation in a subset of FMR1 premutation carriers with FXTAS. The Cerebellum 15(5):641-644. https:// doi.org/10.1007/s12311-016-0798-5

Saghazadeh A, Ahangari N, Hendi K et al (2017) Status of essential elements in autism spectrum disorder: systematic review and meta-analysis. Rev Neurosci 28(7):783-809. https://doi.org/10.1515/revneuro-2017-0015

Sato H, Takahashi S, Suzuki K et al (1996) Change in the concentrations of metal elements in various organs of the mouse following multiple intraperitoneal administration of Ca-DTPA. Jpn J Health Phys 31(1):41-48. https://doi.org/ 10.5453/jhps.31.41

Scassellati C, Bonvicini C, Faraone SV et al (2012) Biomarkers and attention-deficit/hyperactivity disorder: a systematic review and meta-analyses. J Am Acad Child Adolesc Psychiatry 51(10):1003-1019.e20. https://doi.org/10. 1016/j.jaac.2012.08.015
Schneider SN, Liu Z, Wang B et al (2014) Oral cadmium in mice carrying 5 versus 2 copies of the Slc39a8 gene. Int J Toxicol 33(1):14-20. https://doi.org/10.1177/ 1091581813513530

Sreeram N, Wren C, Bhate M et al (1989) Cardiac abnormalities in the fragile X syndrome. Heart 61(3):289-291. https:// doi.org/10.1136/hrt.61.3.289

Tseng PT, Cheng YS, Chen YW et al (2018) Peripheral iron levels in children with autism spectrum disorders vs controls: a systematic review and meta-analysis. Nutr Res 50:44-52. https://doi.org/10.1016/j.nutres.2017.11.004

Verkerk AJ, Pieretti M, Sutcliffe JS et al (1991) Identification of a gene (FMR-1) containing a CGG repeat coincident with a breakpoint cluster region exhibiting length variation in fragile X syndrome. Cell 65(5):905-914. https://doi.org/ 10.1016/0092-8674(91)90397-H

Yasuda H, Yasuda Y, Tsutsui T (2013) Estimation of autistic children by metallomics analysis. Sci Rep 3:1199. https:// doi.org/10.1038/srep01199

Publisher's Note Springer Nature remains neutral with regard to jurisdictional claims in published maps and institutional affiliations. 